ROCZNIKI PEDAGOGICZNE

Tom 11(47), numer specjalny - 2019

DOI: http://dx.doi.org/10.18290/rped.2019.11s-22

ANNA PRUSIK

\title{
OBRAZ RODZINY DYSFUNKCYJNEJ \\ W OPINIACH SKAZANYCH RECYDYWISTÓW PENITENCJARNYCH
}

\section{WPROWADZENIE}

Ludzkie zachowania wyznaczane są przez czynniki biologiczne i środowiskowe, wśród których szczególna uwaga poświęcana jest środowisku rodzinnemu. Rodzina bowiem ma decydujące znaczenie w kształtowaniu osobowości człowieka, jest najistotniejszym miejscem w tworzeniu więzi społecznych, jest podstawą i szkołą życia społecznego. Oznacza to, iż wszelkie zaburzenia i dewiacje w niej występujące mają w późniejszym czasie odzwierciedlenie w zachowaniu dzieci oraz przejawianych przez nie postawach. W przypadku, gdy zakłócenia w rodzinie mają charakter trwały, u dzieci mogą pojawić się aspołeczne zachowania, m.in. takie jak: ucieczki z domów, samouszkodzenia, przynależność do grup nieformalnych, uzależnienia, a także podejmowanie aktywności sprzecznej z prawem.

Funkcjonowanie każdej rodziny jest uzależnione od wielu czynników. Rodzina wypełnia wobec swoich członków wiele funkcji (Adamski, 2002; Tyszka, 2003a; 2003b; Ziemska, 2005; Szendlak, 2010). Im słabiej rodzina wywiązuje się z ciążących na niej obowiązków, tym bardziej jest ona dysfunkcjonalna. Przejawów zaburzeń w funkcjonowaniu rodziny jest wiele. Najczęściej wskazywane są (Ilnicka, 2008, s. 39-41; por. Pierzchała, 2018):

1. Nieprawidłowe postawy rodzicielskie (odtrącenie dziecka - dezaprobata i krytyka dziecka, podejście dyktatorskie, surowe kary, brutalne postępowanie, zastraszanie; postawa unikająca - ignorowanie dziecka, bierność w stosunkach z dzieckiem, unikanie kontaktów z dzieckiem; nadmierne wymagania

Dr Anna Prusik - Wyższa Szkoła Informatyki i Ekonomii TWP w Olsztynie, ul. Jagiellońska 59, 10-283 Olsztyn; e-mail: annaprusik@wp.pl; ORCID: 0000-0002-6258-7447 
- sztywne reguły postępowania, brak samodzielności i odpowiedzialności dziecka w działaniach, ograniczenie swobody i aktywności dziecka; nadmierna ochrona dziecka - przesadna opiekuńczość, nadmierna pobłażliwość, ograniczanie samodzielności, izolowanie od rówieśników.

2. Zaniedbania w zakresie opieki nad dzieckiem (pozbawienie opieki ze strony rodziców, brak zainteresowania czasem wolnym).

3. Zaburzenia w zakresie komunikacji wewnątrzrodzinnej (brak przepływu informacji między członkami rodziny, niejednoznaczność przekazywanych informacji).

4. Nieuświadamianie lub ukrywanie poważnych problemów i konfliktów między członkami rodziny.

5. Brak właściwej atmosfery wychowawczej (brak właściwych postaw, wzorów, trwałych wartości wyniesionych z rodziny pochodzenia).

6. Występujące w rodzinie patologie i uzależnienia.

Zaburzenia prawidłowego funkcjonowania rodziny powodują, iż jej członkowie doświadczają swoistego koszmaru, dom rodzinny nie jest dla nich miejscem bezpiecznym, sprzyjającym zdrowemu rozwojowi i nabywaniu prawidłowych wzorców, a staje się miejscem doświadczania traumy. W literaturze przedmiotu (Strykowska, 2005, s. 49) wskazywane są następujące typy traumatycznej atmosfery rodzinnej:

1. Napięta (nieufność, niedomówienia, poczucie zagrożenia) lub hałaśliwa (częste kłótnie i awantury);

2. Depresyjna (dominacja smutku i rezygnacji);

3. Obojętna (brak więzi uczuciowej rodziców z dzieckiem);

4. Nadmiaru emocji i problemów (dziecko jest zbytnio absorbowane sprawami rodziców).

J. Strykowska (2005) podkreśla, iż traumatycznej atmosferze domu rodzinnego towarzyszy brak zaspokojenia potrzeby bezpieczeństwa, koniecznej do właściwego rozwoju emocjonalnego i społecznego. Obserwowane jest odrzucenie autorytetu dorosłych, norm akceptowanych społecznie i w konsekwencji brak ich przestrzegania w zachowaniu. To właśnie niewłaściwa atmosfera domu rodzinnego, brak dostatecznej opieki nad dzieckiem, stosowanie niewłaściwych metod wychowania, niski poziom moralny rodziców wskazywane są jako główne mechanizmy oddziaływania rodziny na zaburzenia w zachowaniu i nieprzystosowanie społeczne dziecka.

Nie bez znaczenia dla prawidłowego rozwoju dziecka pozostaje także towarzyszące mu w rodzinie poczucie odtrącenia emocjonalnego, częste doświadczanie przez dziecko braku czasu rodziców, braku zainteresowania jego problemami, krytyka postępowania, doświadczanie surowych i dotkliwych 
kar, gróźb wyrzucenia z domu czy umieszczenia w zakładzie wychowawczym (Pospiszyl, Żabczyńska, 1985). Niewątpliwie zjawiskiem negatywnie wpływającym na rozwój dziecka jest także nadmierna koncentracja na nim. Chęć wyswobodzenia się spod przesadnej opieki rodziców w celu zamanifestowania własnej niezależności może prowokować zachowania sprzeczne z przyjętymi zasadami i wartościami (Pytka, Zacharuk, 1998). L. Pytka, T. Zacharuk (1998) podkreślają, iż skłonności antyspołeczne dzieci występują w rodzinach, w których rodzice są wobec siebie wrogo nastawieni, ich relacji towarzyszy gwałtowność, wybuchowość, nerwowość, brak opanowania. Nie bez znaczenia pozostają także doświadczenia przestępcze rodziców i starszego rodzeństwa. Takie sytuacje szczególnie sprzyjają pojawieniu się zachowań przestępczych (Balińska, 2011). Proces demoralizacji młodzieży wiąże się także ze stanem zdrowia rodziców, trwałym kalectwem, chorobami psychicznymi, jak również niskim poziomem wykształcenia i pozycji zawodowej rodziców (Wójcik, 2001).

$\mathrm{Z}$ badań wynika, iż w procesie nabywania zachowań antyspołecznych, szczególnie w przypadku dzieci w wieku adolescencyjnym, zdecydowanie większą rolę odgrywa postawa i zachowanie ojca (Czarnecka-Dzialuk, Drapała, 2016). Wychowywanie dzieci przez samego ojca, który nie utrzymuje z nimi pozytywnych więzi emocjonalnych, także zwiększa prawdopodobieństwo wejścia dziecka w konflikt z prawem (Wójcik, 2001). Do zachowań przestępczych bardziej skłonni są chłopcy pochodzący z rodzin rozbitych, w których matka nie okazywała im wsparcia emocjonalnego (Ignaczak, 2002). Czynnikami, które mogą mieć także wpływ na rozwój zaburzeń w zachowaniu dziecka, są: depresja u matki, wczesne macierzyństwo matki, stosowane surowe metody wychowania, złe warunki socjalne, niskie wykształcenie rodziców, fizyczne i psychiczne maltretowanie dziecka, wykorzystywanie seksualne, dezintegrujący konflikt między rodzicami, antyspołeczne lub kryminalne zachowania w rodzinie, alkoholizm, słaba rodzicielska empatia, słabe wsparcie i komunikacja z dzieckiem, brak zainteresowania rodziców postępami w nauce szkolnej dziecka, wczesne małżeństwo rodziców, rozwód, bardzo liczna rodzina, starsze rodzeństwo z zachowaniami antyspołecznymi, posiadanie rodzeństwa, które popadło już w konflikt z prawem, zachowania kryminalne u ojca, brak wspólnego spędzania wolnego czasu (Kołakowski, 2013).

Dorastanie w rodzinach, w których nie są zaspokajane potrzeby niższego i wyższego rzędu, w których rodzice prezentują niewłaściwe postawy rodzicielskie, nadużywają alkoholu, nie wypełniają prawidłowo swoich zadań pociąga za sobą destrukcyjne konsekwencje dla wszystkich członków rodziny (Prusik, 2000, 2006). Zdaniem J. Mellibrudy (1997, s. 5-7) dzieci wychowywane w rodzinach dysfunkcyjnych w dorosłym życiu borykają się z trudnościami w obszarze: 
poczucia własnej wartości, co często przejawia się brakiem umiejętności radzenia sobie ze złością; poczucia bezpieczeństwa - wyrażanymi nieadekwatnym lękiem; umiejętności kochania i bycia kochanym związanym z poczuciem smutku i nieadekwatnie obniżonego nastroju.

Autor podkreśla, iż można mówić o występowaniu: drażliwości, poczucia pustki i problemów z koncentracją, przedłużającego się napięcia emocjonalnego, smutku, niepokoju oraz lęku wiążącego się z objawami somatycznymi, przewidywań negatywnych konsekwencji podejmowanych działań oraz nadmiernego zamartwiania się przyszłością, zaniżonego poczucia w obszarze własnej wartości i kompetencji, przekonania o samowystarczalności przy jednoczesnym unikaniu podejmowania wyzwań związanych z rozwojem osobistym, sztywności w obszarze oceny zachowań, intencji i emocji swoich oraz osób trzecich.

$\mathrm{Z}$ kolei w relacjach międzyludzkich dorosłe dzieci z rodzin dysfunkcyjnych przejawiają zwykle: lęk przed wchodzeniem w związki; brak umiejętności budowania związków partnerskich, czerpania z tego satysfakcji; nieumiejętność dzielenia się z innymi swoimi emocjami; trudności w obszarze kompetencji społecznych oraz rozwiązywania konfliktów; trudności w konstruktywnym odnalezieniu się w roli rodzica (Krawczyk-Bocian, 2006).

Zaburzenia w zachowaniu wyrażają się na zewnątrz pewnymi manifestacjami, które można uznać za objawy, symptomy zaburzeń zachowania. Symptomy te to zachowania niepokojące, sprzeczne z ogólnie przyjętymi normami i zasadami postępowania (Strykowska, 2005). Podstawowym objawem zaburzeń zachowania jest uparte i powtarzające się łamanie zasad oraz nieliczenie się z prawami innych. Osoby z zaburzeniami zachowania wykazują niedostatki w zakresie zachowań społecznych. Ogólnie przejawiają takie cechy, jak otwarta bądź ukryta wrogość, nieposłuszeństwo, agresja fizyczna lub słowna, kłótliwość, mściwość, skłonność do destrukcji (Carson, Butcher, Nineka, 2005).

Wskazując rozwój zaburzenia, wyrażający się pewnymi manifestacjami, wyróżniono następujące fazy zaburzeń rozwoju (Ilnicka, 2008):

- I fazę, która obejmuje takie manifestacje, jak niepowodzenia w nauce szkolnej, bunt przeciwko autorytetowi, wagarowanie, niestałość emocjonalna;

- II fazę, obejmującą agresywność (bicie, niszczycielstwo), kradzieże i kłamstwa, włóczęgostwo, upór i inne zaburzenia o charakterze neurotycznym;

- III fazę, do której zalicza się całkowitą aspołeczność, obejmującą chuligaństwo i przestępczość.

Sporządzona przez Amerykańskie Towarzystwo Psychiatryczne - Dignostic and Statistical Manual and Mental Disorders - klasyfikacja zaburzeń w zachowaniu wyróżnia zespół niestabilności, zespół zachowania aspołecznego oraz zespół przestępczości. Wskazane kryteria diagnostyczne ujęto w cztery 
grupy (Strykowska, 2005): agresja skierowana na ludzi i zwierzęta; niszczenie własności, dóbr materialnych; kradzieże lub oszustwa; poważne naruszenie reguł obowiązujących w domu i szkole.

Według B. Hołysta (1989) większość przestępców wychowuje się w rodzinach o zaburzonych wzorcach, gdzie ujawniają się agresja, alkoholizm rodziców, porzucenie rodziny przez jednego z rodziców.

$Z$ badań przeprowadzonych przez T. Sakowicza (2006) wynika, że $26 \%$ badanych przestępców odbywających karę pozbawienia wolności dostrzega nieprawidłowe funkcjonowanie rodziny i z tym związane przyczyny niemoralnego postępowania ludzi. Z drugiej strony ci sami przestępcy uznają, że najważniejszą wartością w życiu są wartości rodzinne i dobro rodziny. Licznie reprezentowana grupa badanych, bo $64 \%$ sprawców przestępstw, nie dostrzega problemu, jaki ich dotknął w domu rodzinnym, i pozytywnie wypowiada się o swojej rodzinie pochodzenia. Co istotne, pomimo pozytywnej oceny rodziny, badani uciekali z domu i nie potrafili wyciągnąć właściwych wniosków z błędów popełnionych przez rodziców, ale i z własnych błędów. Autor wskazuje zatem, iż prawdopodobnie jest to pragnienie, marzenie i wola posiadania dobrej własnej rodziny.

\section{OBRAZ RODZINY DYSFUNKCYJNEJ \\ W PAMIĘCI SKAZANYCH RECYDYWISTÓW PENITENCJARNYCH}

Celem podjętych rozważań jest przybliżenie Czytelnikowi opinii recydywistów penitencjarnych na temat zdarzeń i niekorzystnych sytuacji mających miejsce $w$ ich rodzinach pochodzenia, które mogły determinować podejmowane przez nich decyzje. Badania na temat następstw dorastania w rodzinie dysfunkcjonalnej i dzieciństwa skazanych przeprowadzono pod kierunkiem dr Anny Prusik, w ramach seminarium magisterskiego ${ }^{1}$. Zastosowano metodę sondażu diagnostycznego, technikę ankietowania. Kwestionariusze ankiety pozwalające rozpoznać opinie osadzonych na temat ich domu rodzinnego, atmosfery życia rodzinnego zostały skierowane do recydywistów penitencjarnych. W badaniach wzięli udział tylko osadzeni wskazani przez psychologa pracującego w Zakładzie Karnym jako pochodzący z rodzin dysfunkcyjnych. Badania zostały

\footnotetext{
${ }^{1}$ K. GLiBowsKa, Konsekwencje dorastania w rodzinie dysfunkcjonalnej na podstawie badań skazanych recydywistów penitencjarnych $w$ Zakładzie Karnym w Kamińsku, mps pracy magisterskiej, Olsztyn, 2017.
} 
przeprowadzone w grupie 50 osób obywających karę pozbawienia wolności w Zakładzie Karnym w Kamińsku.

Problem główny przybrał postać następującego pytania:

- Jakie są opinie osadzonych na temat dorastania w rodzinach dysfunkcjonalnych?

Wyodrębniono także następujące problemy szczegółowe:

- W jaki sposób osadzeni oceniają relacje między członkami rodziny panujące w ich rodzinie pochodzenia?

- Jaka atmosfera domu rodzinnego towarzyszyła osadzonym w dzieciństwie?

- Czy osadzeni doświadczali w dzieciństwie wsparcia ze strony najbliższych?

- Czy osadzeni byli zachęcani do podejmowania różnych form aktywności, rozwoju zainteresowań?

- Czy w domu rodzinnym skazanych stosowano przemoc?

- Czy w domu rodzinnym skazanych występowały uzależnienia?

Sformułowaną hipotezę główną stanowi twierdzenie mówiące, iż osadzeni wyrażają negatywne opinie na temat swoich rodzin pochodzenia.

Szczegółowe hipotezy badawcze:

- Zakłada się, iż osadzeni negatywnie oceniają relacje między członkami rodziny.

- Zakłada się, iż osadzonym w domu rodzinnym towarzyszyła zła, toksyczna atmosfera.

- Zakłada się, iż osadzeni nie doświadczali w dzieciństwie wsparcia ze strony najbliższych.

- Zakłada się, iż osadzeni nie byli zachęcani do podejmowania różnych form aktywności i rozwoju zainteresowań.

- Zakłada się, iż w domu rodzinnym osadzonych stosowano przemoc.

- Zakłada się, iż w domu rodzinnym osadzonych występowały uzależnienia. Ze względu na ramy niniejszego opracowania prezentowane są jedynie wybrane opinie, które sprzyjają rozpoznaniu złożonej relacji między funkcjonowaniem środowiska rodzinnego a negatywnym zachowaniem człowieka i podejmowanymi przez niego wyborami.

W badaniach udział wzięli wyłącznie mężczyźni (50 osób). Zdecydowana większość z nich (64\%) wskazała wieś jako miejsca zamieszkania, a pozostali (36\%) byli mieszkańcami miast. Większość respondentów (61\%) żyje w związku małżeńskim. 
Tabela 1. Struktura wieku badanych

\begin{tabular}{|l|r|c|}
\hline \multicolumn{1}{|c|}{ Wiek } & $N$ & $\%$ \\
\hline $20-25$ & 5 & 10 \\
\hline $26-30$ & 12 & 25 \\
\hline $31-40$ & 9 & 17 \\
\hline $41-50$ & 17 & 33 \\
\hline $51-55$ & 4 & 9 \\
\hline $56-60$ & 3 & 6 \\
\hline Razem & 50 & 100 \\
\hline
\end{tabular}

Źródło: badania własne.

Najliczniej reprezentowaną grupą osób biorących udział w badaniach byli osadzeni w wieku 41-50 lat (33\% ogółu badanych). Najmniej liczną grupę stanowili osadzeni w wieku 55-60 lat (6\%).

Spośród osadzonych biorących udział w badaniach najliczniejsza grupa (19 osób) wskazała, że ma wykształcenie zawodowe, 15 osób - wykształcenie podstawowe, 10 osób - wykształcenie średnie, natomiast wykształcenie gimnazjalne - 5 osób, tylko jedna osoba legitymowała się wykształceniem wyższym.

Tabela 2. Status zawodowy przed rozpoczęciem odbywania kary pozbawienia wolności

\begin{tabular}{|l|c|c|}
\hline \multicolumn{1}{|c|}{ Status zawodowy } & $N$ & $\%$ \\
\hline Bezrobotny & 23 & 47 \\
\hline Pracujący & 17 & 33 \\
\hline Rencista & 10 & 20 \\
\hline Emeryt & 0 & 0 \\
\hline Razem & 50 & 100 \\
\hline
\end{tabular}

Źródło: badania własne.

Blisko połowa osób (47\%) biorących udział w badaniach przed odbywaniem kary pozbawienia wolności nie pracowała zawodowo. Rentę jako źródło utrzymania wskazało $20 \%$ spośród badanych osadzonych.

Tabela 3. Długość odbywania kary pozbawienia wolności

\begin{tabular}{|l|r|r|}
\hline Długość odbywania kary pozbawienia wolności & $N$ & $\%$ \\
\hline Powyżej 5 lat & 3 & 6 \\
\hline 3-5 lat & 23 & 47 \\
\hline 1-3 lat & 16 & 32 \\
\hline Do 1 roku & 8 & 15 \\
\hline Razem & 50 & 100 \\
\hline
\end{tabular}

Źródło: badania własne 
Blisko połowa osadzonych biorących udział w badaniach (47\%) odbyła karę pozbawienia wolności zasądzoną w przedziale od 3 do 5 lat. Z kolei karę pozbawienia wolności do 1 roku odbywa $15 \%$ badanych. Karę pozbawienia wolności powyżej 5 lat odbywa $6 \%$ spośród nich.

Zakładając, iż rodzina ma decydujące znaczenie w kształtowaniu osobowości człowieka i jest ważnym miejscem tworzenia więzi społecznych, przyswajania norm i wzorców postępowania, ważne było rozpoznanie opinii badanych na temat struktury i funkcjonowania ich rodzin macierzystych. Zwłaszcza iż wszelkie zaburzenia i dewiacje występujące w rodzinie mają w późniejszym czasie odzwierciedlenie w zachowaniu dzieci oraz przejawianych przez nie postawach.

Połowa osób biorących udział w badaniach (50\%) wskazała, iż dorastała w rodzinie niepełnej. W rodzinie pełniej, z obojgiem rodziców, dorastało $44 \%$ badanych. Natomiast $6 \%$ badanych wskazało, iż wychowywało się w rodzinie zastępczej. Większość osób biorących udział w badaniach pochodzi z rodzin wielodzietnych. Czworo dzieci w rodzinie wskazało $38 \%$ badanych, sześcioro dzieci w rodzinie wskazało $24 \%$ osadzonych, troje dzieci w rodzinie wskazało $18 \%$ badanych.

Nie bez znaczenia dla jakości realizacji funkcji rodziny i jej zadań pozostaje wykształcenie i status zawodowy rodziców, ich uczestnictwo w rynku pracy. Blisko połowa osadzonych (46\%) wskazała, iż ich matka ma wykształcenie średnie, z kolei $42 \%$ badanych podało, że matka ma wykształcenie zawodowe, a $8 \%$ badanych - że ma ona wykształcenie podstawowe. Tylko jedna osoba wskazała wykształcenie matki jako wyższe. Przeszło połowa badanych (56\%) podała, że ojciec ma wykształcenie zawodowe, $26 \%$ - że ojciec ukończył szkołę średnią, a 18\% - że ojciec ma wykształcenie podstawowe. Żaden z osadzonych nie wskazał, by ojciec miał wyższe wykształcenie.

Z kolei udzielając informacji na temat statusu zawodowego rodziców, ponad połowa osadzonych (56\%) wskazała, że ich matki pracują zawodowo, 30\% osadzonych - że ich matki są bezrobotne. Na rencie przebywało $10 \%$ matek, matka jednej osoby przebywa na emeryturze. W przypadku statusu zawodowego ojca największą grupę (40\%) stanowili bezrobotni ojcowie osadzonych, z kolei $38 \%$ badanych miało ojców pracujących zawodowo. Rentę miało $18 \%$ ojców, jedna osoba wskazała, iż ojciec przebywa na emeryturze.

Część rodzin osadzonych borykała się z trudnościami ekonomicznymi, w wypowiedziach wskazywano trudną sytuację materialno-bytową rodzin, a w przypadku przeszło połowy rodzin osadzonych (55\%) ograniczano wydatki na jedzenie.

Osoby biorące udział w badaniach wypowiadały się na temat atmosfery wychowawczej panującej w domu rodzinnym i relacji między członkami rodziny. 
Wypowiedzi badanych ukazują obecny w literaturze przedmiotu pogląd, iż osoby popadające w konflikt z prawem często wychowują się w rodzinach o zaburzonych wzorcach, w których ujawniają się agresja, przemoc, uzależnienia. Większość respondentów (60\%) stwierdziła, iż w domu rodzinnym panowała zła, toksyczna atmosfera, wprowadzająca w stan nerwowości, chaosu, braku poczucia bezpieczeństwa. Zdaniem tej grupy badanych dom rodzinny nie był miejscem bezpiecznym, sprzyjającym zdrowemu rozwojowi i nabywaniu prawidłowych wzorców, a raczej miejscem doświadczania traumy. Natomiast spośród badanych $10 \%$ osadzonych wskazało, iż w domu rodzinnym „bywało różnie". Natomiast 30\% osadzonych określiło atmosferę rodzinną jako dobrą, w której panowały prawidłowe relacje. Te same osoby wskazywały, iż odczuwały w domu rodzinnym wsparcie rodziców.

Zdecydowana większość, bo aż $70 \%$ badanych, wypowiedziała się negatywnie na temat ewentualnego wsparcia oferowanego $\mathrm{w}$ dzieciństwie przez rodziców. Ta grupa badanych stała na stanowisku, iż w domu rodzinnym nie doświadczyła od rodziców wsparcia ani pomocy w zakresie realizacji zadań czy podejmowanych wyborów. W tej grupie badanych określano atmosferę domu rodzinnego jako pełną obojętności, braku umiejętności komunikacji pomiędzy członkami rodziny i zaspokojenia potrzeb, $34 \%$ badanych zaznaczyło, iż rodzice nie interesowali się ich edukacją, nie oferowali pomocy w zakresie odrabiania lekcji. Co istotne, większość (60\%) osadzonych biorących udział w badaniach nie wykonywała w domu rodzinnym żadnych obowiązków. Aż $80 \%$ osadzonych regularnie wagarowało, a $76 \%$ wdawało się w bójki w szkole, sprawiało problemy wychowawcze.

Zdecydowana większość (76\%) badanych wskazywała, iż rodzice nie zachęcali ich do rozwijania zainteresowań, hobby. W wypowiedziach osadzonych wybrzmiał także brak zainteresowania rodziców czasem wolnym ich dzieci. Osadzeni wskazywali, iż jako dzieci swój czas wolny spędzali ze znajomymi (38\%), grali w gry komputerowe (28\%), oglądali telewizję (20\%). Jedynie 4\% badanych stwierdziło, że w czasie wolnym rozwijali swoje zainteresowania, hobby, $2 \%$ badanych brało udział w dodatkowych zajęciach, $6 \%$ uprawiało sport, a $2 \%$ badanych słuchało samotnie muzyki w swoim pokoju.

Rozpoznając atmosferę domu rodzinnego, stopień poczucia zaufania, życzliwości, wzajemne relacje, starano się dociec, czy osadzeni komunikowali rodzicom swoje problemy i radości. Zdecydowana większość badanych (76\%) udzieliła odpowiedzi negatywnej w tym zakresie. Może to świadczyć o słabej relacji między członkami rodziny, braku poczucia więzi emocjonalnej i braku umiejętnej komunikacji w rodzinie. Brak życzliwych relacji między członkami rodziny uwidacznia się także w wypowiedziach osadzonych, którzy wskazują, 
iż w domach rodzinnych nie czuli się doceniani, nie byli chwaleni. W takim tonie wypowiedziała się zdecydowania większość (80\%) osadzonych biorących udział badaniach. Tylko $20 \%$ badanych podało, że rodzice chwalili ich m.in. za oceny w szkole, za zachowanie, za utrzymywanie porządku w swoim pokoju.

W rodzinach dysfunkcyjnych, które nie wypełniają prawidłowo swoich funkcji, często obecne są uzależnienia. Osadzonych poproszono o udzielenie informacji na temat uzależnień występujących w domu rodzinnym. Większość osadzonych biorących udział w badaniach (66\%) wskazała, że w ich rodzinach nadużywano alkoholu. Najczęściej osobą nadużywającą alkohol w rodzinie był ojciec - tak podało $46 \%$ osadzonych. $Z$ kolei $26 \%$ badanych zaznaczyło, iż to matka nadużywała alkoholu, $22 \%$ badanych wskazało oboje rodziców jako nadużywających alkoholu, a 6\%, że to rodzeństwo nadużywało alkoholu. Spośród badanych $34 \%$ wypowiedziało się negatywnie na ten temat. W rodzinach osób osadzonych dochodziło także do sytuacji zażywania narkotyków - tak stwierdziło $22 \%$ badanych. W tej grupie osób połowa badanych wskazała, iż narkotyki zażywało rodzeństwo, $25 \%$ osadzonych wskazało matkę i $25 \%$ ojca jako osoby zażywające narkotyki. Dorastanie w środowisku dysfunkcyjnym może sprzyjać wczesnej inicjacji alkoholowej. Badani wskazywali wiek, w którym po raz pierwszy spróbowali alkoholu: $10 \%$ badanych po raz pierwszy spożyła alkohol przed 13 rokiem życia, 40\% - między 13 a 15 rokiem życia, 25\% - między 15 a 17 rokiem życia, $15 \%$ - między 17 a 19 rokiem życia, $10 \%$ - po 19 roku życiu. Przeszło połowa osadzonych (56\%) zażywała narkotyki. W tej grupie osób $6 \%$ wskazało, iż pierwszy kontakt z narkotykami miał miejsce w wieku do 13 roku życia, 34\% - między 13 a 15 rokiem życia, 30\% - między 15 a 17 rokiem życia, 16\% między 17 a 19 rokiem życia, a 14\% - powyżej 19 roku życia.

Nadużywaniu alkoholu i narkotyków często towarzyszy stosowanie przemocy. Większość osadzonych (70\%) w dzieciństwie doświadczała kar fizycznych, była wobec nich stosowana przemoc. Najczęściej (50\%) osadzeni wskazywali kary fizyczne (bicie pasem lub innym przedmiotem), a także zakazy wyjścia z domu, zakazy spotkań ze znajomymi (20\%), zakaz korzystania z komputera (20\%), zakaz oglądania telewizji (8\%), zakaz otrzymywania posiłku (2\%). Wobec osadzonych rodzice stosowali także groźby, np. wyrzucenia z domu. W takim tonie wypowiedziało się $68 \%$ ogółu badanych. W rodzinach dysfunkcyjnych dzieci często są świadkami sytuacji przemocowych. Badane osoby z większości (60\%) wskazały, iż były świadkami bójki rodziców.

W domach rodzinnych osadzonych obecna była agresja, której doświadczali zarówno ze strony ojca, jak i matki - 70\% badanych miało agresywnego ojca, a 30\% osadzonych agresywnie zachowującą się w stosunku do nich matkę. Ojcowie byli zdecydowanie bardziej agresywni wobec osadzonych niż matki. 
Nie zmienia to jednak faktu, iż oboje rodzice przejawiali zachowania agresywne w stosunku do swoich dzieci. Wobec powyższych faktów nie może dziwić, iż osoby biorące udział w badaniach podejmowały w dzieciństwie próby ucieczki z domu rodzinnego. Większość osadzonych biorących udział w badaniach (66\%) ma za sobą takie doświadczenie.

Część osadzonych (68\%) przebywała w domu dziecka. Osadzeni (52\% badanych) przebywali także w zakładach poprawczych, opiekuńczych, szkolno-wychowawczych.

W literaturze przedmiotu obecny jest pogląd, iż dorastanie w środowisku dysfunkcyjnym (por. Pierzchała, 2016) sprzyja sytuacjom, w wyniku których młodzi ludzie popadają w konflikt z prawem. Połowa (50\%) recydywistów penitencjarnych biorących udział w badaniach po raz pierwszy trafiła do aresztu między 21 a 25 rokiem życia; 24\% badanych - między 26 a 30 rokiem życia, natomiast $20 \%$ - między 31 a 35 rokiem życia, a $6 \%$ badanych pierwszy wyrok usłyszało przed 21 rokiem życia. Przeszło połowa badanych $(62 \%)$ wskazała, iż ich bliscy także odbywali kary pozbawienia wolności, przebywali w zakładach karnych. W tej grupie badanych $70 \%$ wskazało ojca jako tego, który odbywał karę w zakładzie karnym, 28\% osadzonych wskazało rodzeństwo, a $10 \%$ badanych - matkę. $Z$ kolei jedna osoba wskazała, iż oboje rodzie mieli takie doświadczenia.

\section{PODSUMOWANIE}

Przywołując w pamięci obraz domu rodzinnego, osadzeni w większości wskazywali na traumatyczne, niekorzystne sytuacje, których doświadczali w dzieciństwie. W części rodzin wskazywane było nadużywanie alkoholu przez bliskich, osadzeni byli świadkami kłótni, bójek, także sami doświadczali przemocy fizycznej i psychicznej. W niektórych rodzinach borykano się z trudnościami ekonomicznymi, a nawet ograniczano wydatki na jedzenie. Rodzice zaniedbywali swoje obowiązki w zakresie opieki nad dzieckiem, nie interesowali się jego problemami i organizacją czasu wolnego. Brak właściwej atmosfery wychowawczej w domu rodzinnym oraz brak umiejętności komunikacji wewnątrzrodzinnej wybrzmiał $\mathrm{w}$ większości wypowiedzi badanych osób. Taki stan rzeczy, występujące w rodzinie patologie i uzależnienia prowokowały osadzonych do ucieczek $\mathrm{z}$ domu rodzinnego (18\% badanych dom rodzinny kojarzy z miejscem, do którego nie chce wracać). Pomimo to, część osadzonych (40\%), wspominając dom rodzinny, traktuje go jako „normalny”. Wyniki badań są zbieżne z dostępnymi w literaturze (Hołyst, 1989; Sakowicz, 
2006; Pierzchała, 2013; 2015), zgodnie z którymi zachodzi zależność między dorastaniem w dysfunkcyjnym środowisku rodzinnym, w którym ujawniają się agresja, alkoholizm rodziców, brak wsparcia, brak prawidłowych wzorców a popadaniem w konflikt z prawem.

\section{BIBLIOGRAFIA}

Adamski, F. (2002). Rodzina. Wymiar społeczno-kulturowy. Kraków: Wydawnictwo UJ.

BALIŃSKA, K. (2011). Wpływ środowiska rodzinnego na przestęczość nieletnich. Katowice: Wydawnictwo UŚ.

Carson, R.C., Butcher, J.N., Mineka, S. (2005). Psychologia zaburzeń. Gdańsk: Gdańskie Wydawnictwo Psychologiczne.

Czarnecka-Dzialuk, B., Drapala, K. (2016). Zagadnienia recydywy nieletnich w świetle badań zagranicznych i polskich. W: G. KUDLAK (red.), Instytucjonalna resocjalizacja nieletnich (s. 28). Warszawa: Wyd. Difin.

HoŁyst, B. (1989). Nieprzystosowanie społeczne dzieci i młodzieży. Warszawa: PWN.

IgNACZAK, M. (2002). Wartości rodziców a agresja interpersonalna ich synów. W: A. FrączeK (red.), Studia nad uwarunkowaniami i regulacja agresji interpersonalnej (s. 73). Wrocław: Ossolineum.

ILnicka, R. M. (2008). Środowiskowy kontekst niedostosowania społecznego młodzieży. Toruń: Wydawnictwo Edukacyjne „AKAPIT” s.c.

KoŁakowski, A. (2013). Zaburzenia zachowania u dzieci. Teoria i praktyka. Sopot: Gdańskie Wydawnictwo Psychologiczne.

Krawczyk-Bocian, A. (2006). Proces tworzenia tożsamości u Dorosłych Dzieci Alkoholików. W: M. DeptuŁa (red.), Diagnostyka i profilaktyka w teorii i praktyce pedagogicznej (s. 356368). Bydgoszcz: Wydawnictwo UKW.

Mellibruda J. (1997). DDA - kim właściwie są. Świat Problemów, 10, 5-7.

PierzchaŁA, K. (2013). Kapelan więzienny w procesie resocjalizacji penitencjarnej. Toruń: Wydawnictwo Adam Marszałek.

Pierzcha£a, K. (2015). Skazani ale nie potepieni. Wyd. II rozszerzone. Toruń: Wydawnictwo Adam Marszałek.

Pierzchala, K. (2016). Destygmatyzacja przestępców w świetle Magisterium Kościoła oraz poglądów na resocjalizację. Kraków: Oficyna Wydawnicza „Impuls”.

Pierzchala, K. (2018). Forms of Rehabilitation's Effects Toward Dysfunctional Family [Formy oddziaływania resocjalizującego wobec dysfunkcjonalnej rodziny]. W: M. PrzyBYsz-ZAremBA, W. ZiareK (red.), FAMILY. Tasks - Help - Support. Selected Aspects (s. 249-263). Lithuania: Mykolas Romeris University in Vilnius. Academic Editing.

Pospiszyl, K., ŻABCzyńska, E. (1985). Psychologia dziecka niedostosowanego społecznie. Warszawa: PWN.

Prusik, A. (2000). Postawy rodzicielskie matek i ojców nadużywających alkoholu w percepcji dzieci. Z doświadczeń pedagoga. Kwartalnik Pedagogiczny, 1, 117-128. 
Prusik, A. (2006). Wpływ ról pełnionych przez dzieci w rodzinach z chorobą alkoholową. Świat Problemów, 3, 31-33.

Pytka, L. (1993). Nieprzystosowanie społeczne i jego odmiany. W: W. PomykaŁo (red.), Encyklopedia pedagogiczna (s. 454). Warszawa: Fundacja Innowacja.

Pytka, L., Zacharuk, T. (1998). Zaburzenia przystosowania społecznego dzieci i młodzieży. Siedlce: Wyższa Szkoła Rolniczo-Pedagogiczna.

SAKowicz, T. (2006). Dysfunkcjonalność rodziny a resocjalizacja. Kraków: Oficyna Wydawnicza „Impuls”.

Stry kowska, J. (2005). Niedostosowanie społeczne dzieci w wieku szkolnym. Gniezno: Gnieźnieńska Wyższa Szkoła Humanistyczno-Menadżerska MILENIUM.

Szlendak, T. (2010). Socjologia rodziny. Ewolucja, historia, zróżnicowanie. Warszawa: Wydawnictwo Naukowe PWN.

Tyszka, Z. (2003a). Rodzina we wspótczesnym świecie. Poznań: UAM.

TYSZKA, Z. (red.) (2003b). Życie rodzinne - uwarunkowania makro i mikrostrukturalne. Poznań: UAM.

Wóscik, D. (2001). Nieprzystosowanie społeczne młodzieży. Analiza psychologiczno-kryminologiczna. Wrocław: Zakład Narodowy im. Ossolińskich.

Ziemska, M. (red.) (2005). Rodzina współczesna. Warszawa: Wydawnictwo UW.

\section{OBRAZ RODZINY DYSFUNKCYJNEJ \\ W OPINIACH SKAZANYCH RECYDYWISTÓW PENITENCJARNYCH}

Streszczenie

W artykule podjęto próbę ukazania wybranych konsekwencji dorastania w dysfunkcyjnym środowisku rodzinnym. W wypowiedziach osadzonych recydywistów penitencjarnych na temat funkcjonowania ich rodzin macierzystych wybrzmiewa potwierdzenie poglądu, iż ludzkie zachowania determinowane są w znacznej mierze przez czynniki środowiskowe, wśród których szczególną rolę odgrywa środowisko rodzinne.

Słowa kluczowe: rodzina dysfunkcyjna; osadzeni.

\section{AN IMAGE OF A DYSFUNCTIONAL FAMILY \\ IN THE OPINIONS OF CONVICTED PENITENTIARY RECIDIVISTS}

\section{Summary}

The article attempts to show selected consequences of growing up in a dysfunctional family environment. In the statements of prisoners convicts about the functioning of their families, the view is confirmed that human behavior is determined to a large extent by environmental factors, among which the family environment plays a special role.

Key words: dysfunctional family; prisoners. 